\title{
Age, Growth and Length-weight Relations of Common Sole (Solea solea Linnaeus, 1758) from Southern Aegean Sea
}

\author{
Hasan Cerim ${ }^{1}$ (D), Celal Ateş ${ }^{1}$ (D)
}

Cite this article as: Cerim, H., Ateş, C. Age, growth and length-weight relations of common sole (Solea solea Linnaeus, 1758) from Southern Aegean Sea. Aquatic Sciences and Engineering, 35(2), 36-42.

ORCID IDs of the authors: H.C. $0000-0003-3025-1444$ C.A. $0000-0003-0533-4512$

'Muğla Sıtkı Koçman University, Faculty of Fisheries, Muğla, Turkey

Submitted:

25.07.2019

Revision Requested:

06.12.2019

Last Revision Received:

07.01.2020

Accepted:

14.01.2020

Online published:

28.01.2020

Correspondence:

Hasan Cerim

E-mail:

hasancerim@gmail.com

(C) Copyright 2020 by Aquatic Sciences and Engineering Available online at

https://dergipark.org.tr/ase

\begin{abstract}
In this study, age and sex compositions, length distributions, growth parameters and length-weight relationships of common sole populations were determined in Güllük Bay, southern Aegean Sea, Turkey. Trammel nets and beach seines which have different full mesh sizes were used to obtain samples. Sex ratio (female:male) was found to be 1.14:1. Growth parameters of the common sole in Güllük Bay was described as; $L_{\infty}=33.95, K=0.208 y^{-1}, t_{0}=-0.032, L_{\infty}=31.98, K=0.236 y^{-1}, t_{0}=-0.037$ y and $L_{\infty}=29.11, K=0.324 y^{-1}, t_{0}=-0.030 y$, for sexes combined, females and males, respectively. Lengthweight relationships for combined sexes, females and males were $W=0.0079 L^{3.064}, W=0.0072 L^{3.101}$ and $W=0.0088 \mathrm{~L}^{3.024}$, respectively. Combined individuals and females showed positive allometric growth and males showed isometric growth. Ages ranged between 0-9 years. Study results could be useful for further common sole fishery management strategies.
\end{abstract}

Keywords: Common sole, Aegean Sea, trammel net, small-scale fishery, flatfish

\section{INTRODUCTION}

Flatfishes are a highly diverse fish group. According to taxonomists, 1820 species have been identified, however, 1073 are valid and the Soleidae family includes approximately 281 species (181 valid species) (Eschmeyer \& Fong, 2017). 56 of these flatfish species have commercial importance all over the world and 10 in the Mediterranean (Ulutürk, 2012). In Turkey, a few turbots, sole and flounder species are commercial (TUIK, 2016). Common sole (Solea solea) is one of the highest commercial flatfish species in Turkey (Türkmen, 2003) as in some other parts of the world (Teixeira, 2007). Therefore, it is a targeted species by fishermen in some periods.

Güllük Bay is an important fishery area for both small-scale and industrial fisheries. Beside trawling and purse-seining, small-scale fishery (especially trammel net fishery) is common in this area. Species-specific fishing gear (such as red mullet nets, shrimp nets, common dentex nets etc.) are densely used. One of these nets is the common sole trammel net and is used in certain periods in Güllük Bay. Especially, the period which is from the middle of September to the middle of February, is locally named as common sole period.

Due to having high commercial importance, the common sole stocks need proper management strategies. Therefore, there have been many studies conducted on common sole including growth (Deniel, 1990; Enberg et al., 2008), stock assessment (Mehanna \& Salem, 2012), and population parameters (Türkmen, 2003).

Common sole studies are both discontinuous and insufficient in Turkey. The objective of the present study was to determine age and sex compositions, length distributions, growth parameters and length-weight relationships of the common sole population in Güllük Bay for further fishery management strategies. 


\section{MATERIALS AND METHODS}

Fishing operations were conducted between October 2013 November 2015 in Güllük Bay and Boğaziçi lagoon, which are in the Southern Aegean Sea, Turkey (Figure 1).

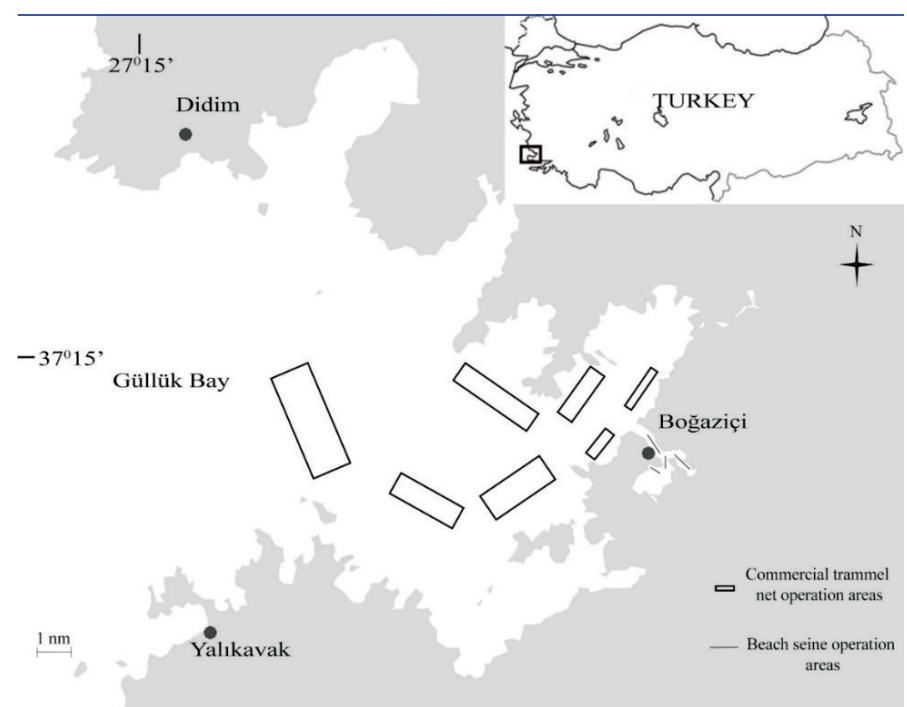

Figure 1. Study area (Cerim, 2017).

Samplings consisted of two parts; first was just total length measurement on board due to difficulties of taking weights of the specimens by a digital laboratory scale, second was laboratory examinations for length, weight and age determinations.

Data were obtained from commercial small-scale fishermen who use $80-90 \mathrm{~mm}$ full mesh size trammel nets. Additionally, beach seine and 52-56-64 mm full mesh size PA trammel nets were used to obtain various length classes in the lagoon area. Sampling depths varied between $0.5 \mathrm{~m}$ and $70 \mathrm{~m}$. Samples were stored in ice and were brought to the laboratory.

Total lengths were measured to the nearest $0.1 \mathrm{~cm}$ and weighed individually to the nearest $0.01 \mathrm{~g}$. Sagittal otoliths were removed, cleaned and stored in Eppendorf tubes. Otoliths were embedded in polyester, and two thin sections $(0.1 \mathrm{~mm})$ were cut along a transverse plane through the focus of the otolith by a Buehler Isomet Lowspeed Saw. The ages were read under a light microscope by three independent experts. Contradictory readings were discarded from age estimations. The theoretical birthday was considered as 1 January (Froglia \& Giannetti, 1985). Exact ages were calculated according to sampling month (1 month $=0.083$ year).

Length weight relationships were calculated according to formula $W=a^{*} L^{b}$ (Ricker, 1973). Where; $L$ is the total length, $W$ is the total weight, $a$ is the intercept of the regression curve and $b$ is the regression coefficient. If $b$ value is $3,<3$ or $>3$, it means isometry, negative allometry and positive allometry, respectively. Significant difference of $b$ values from 3 were tested with the t-test (Pauly, 1993).

Growth coefficient $(K)$, age at zero length $\left(t_{0}\right)$ and asymptotic length $\left(L_{\infty}\right)$ were estimated with the least square method (Legendre, 1805).
The Chi-square $\left(\chi^{2}\right)$ test was used to examine significant differences $(p<0.05)$ between sexes.

Growth performance was estimated with the phi-prime test $(\varnothing)$ (Pauly and Munro, 1984);

$$
\varnothing=\log K+2 \log L \infty .
$$

\section{RESULT AND DISCUSSION}

\section{On board measurements and laboratory examinations}

In total, 2165 individuals were evaluated in the study. The total length of 1029 individuals were recorded on board. The total lengths varied between 19.1 and $42.1 \mathrm{~cm}$ (Figure 2). The maximum total length, $42.1 \mathrm{~cm}$, was measured on board. It was not possible to determine the sexes of the individuals on board.

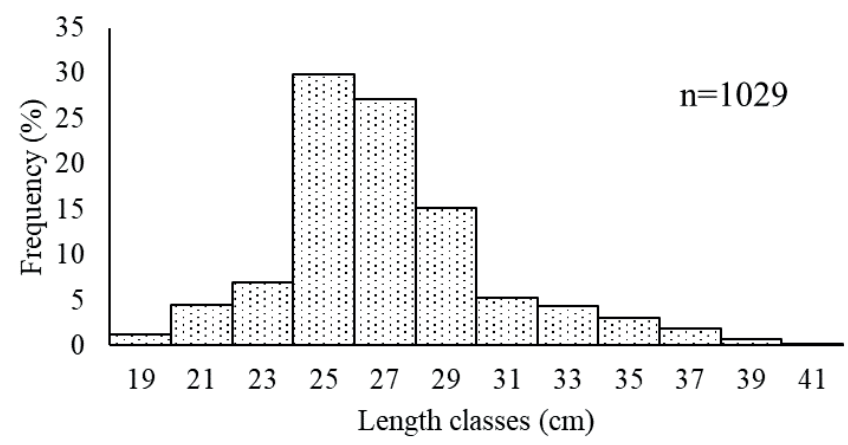

Figure 2. Length-frequency of on board measurements.

According to laboratory examinations, 1136 individuals were evaluated and 607 of the individuals were female and 529 individuals were male. Sex ratio was found as 1.14:1, female to male, respectively. According to the chi square test, a significant difference was found between female and male $\left(p<0.05, \chi^{2}=5.35\right)$.

Female total lengths ranged between $7.1-31.1 \mathrm{~cm}$ and male total lengths ranged between 3.9-28.7 cm (Figure 3).

Total lengths and weights of 1136 individuals were evaluated to determine length and weight relations. Total lengths ranged

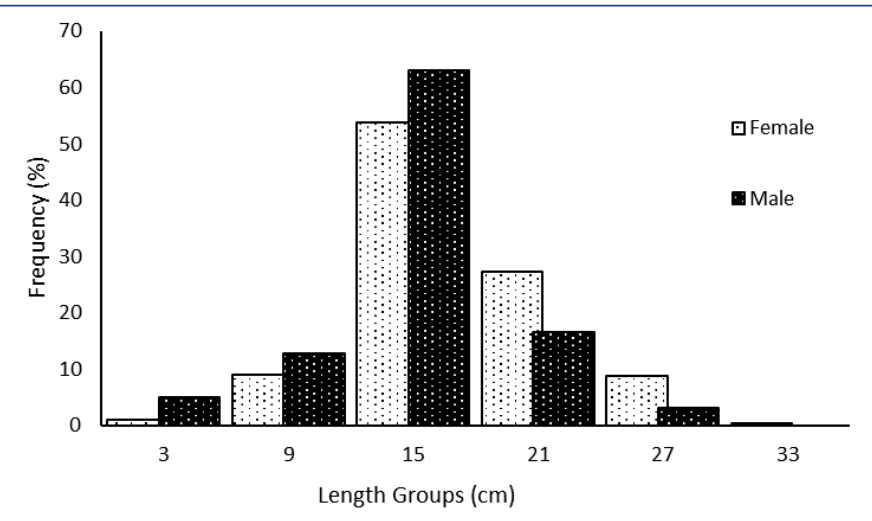

Figure 3. Total length-frequency of common sole. 
Table 1. Total length-weight parameters

\begin{tabular}{|c|c|c|c|c|c|c|c|}
\hline Sex & $n$ & $a$ & $b$ & C.I. of $b$ & S.E. of $b$ & $\mathbf{R}^{2}$ & Growth Type \\
\hline Combined & 1136 & 0.0079 & 3.064 & $3.046-3.080$ & 0.03617 & 0.9915 & $A+$ \\
\hline Female & 607 & 0.0072 & 3.101 & $3.085-3.139$ & 0.03535 & 0.9866 & $A+$ \\
\hline Male & 529 & 0.0088 & 3.024 & $2.997-3.042$ & 0.03586 & 0.9925 & I \\
\hline
\end{tabular}

from 3.9 to $31.1 \mathrm{~cm}$ and weights ranged from 0.24 to $458.67 \mathrm{~g}$. Total lengths and weight regressions were calculated for combined sexes, females and males, separately. $b$ values of combined, female and male individuals were compared with isometric growth. While combined individuals and females showed positive allometric growth ( $p>0.05)$, males showed isometric growth $(p<0.05)$ (Table 1).

Length-frequency distributions provide a vision (Khan \& Khan, 2014) to help understand when the fishing pressure starts and ends. Length range $(2.9-42.1 \mathrm{~cm})$ shows us the significance of the area in terms of maintaining common sole's generations. According to Turkish fishery communiques, the minimum landing size of common sole is $20 \mathrm{~cm}$. However, an individual with only $9.1 \mathrm{~cm}$ total length was caught in a commercial $52 \mathrm{~mm}$ trammel net. Capture of small individuals by commercial nets means fishing pressure is at the beginning of the common sole lifespan. Cerim \& Ateş (2016) found optimum catch sizes to be 23.20 and $27.02 \mathrm{~cm}$ for $80 \mathrm{~mm}$ and $90 \mathrm{~mm}$ full mesh sized trammel nets, respectively. These findings are suitable in terms of length-based fishery management. However, the $16-22 \mathrm{~cm}$ length range (the second most observed length range in length-frequency distribution) originated from lagoon samplings $(52,56$ and $64 \mathrm{~mm}$ full mesh size trammel nets). According to length-frequency distributions, as a great majority of small individuals are captured in the lagoon area, Boğaziçi lagoon area could be characterized as a spawning or nursery area. Therefore, lagoon fisheries should be managed by taking into consideration this feature. On the other hand, if the fishing pressure exceeds the optimal population growth, common sole stocks may collapse in the future.

\section{Age determinations}

The otoliths of 235 individuals were used for age determination. Fishes were chosen randomly to obtain various length classes without considering their sexes. Therefore, the number of females and males varies.

Ages were between 0-9 years. Ages distributed between 1-8 year for females (148 individuals) and 1-7 years for males (75 individuals) (Figure 4). For some fish, sex determinations were impossible due to having too small or transparent gonads and no internal organs (occasionally, internal organs are eaten by an Isopod species after the fish is entangled in the net). However, these individuals (i.e. 12 unsexed individuals) were incorporated into age determination (some of 0,8 and 9 years old individuals belong to this unsexed group). Length related ages of combined females and males are shown in Tables 2, 3 and 4.

Length at ages are given in Table 5. Methods of the previous studies' age determinations were similar. However, some of the total lengths which were related to their ages in other previous studies, are larger or smaller than the present study results. First$l y$, the difference in size-compositions could be an effect on these

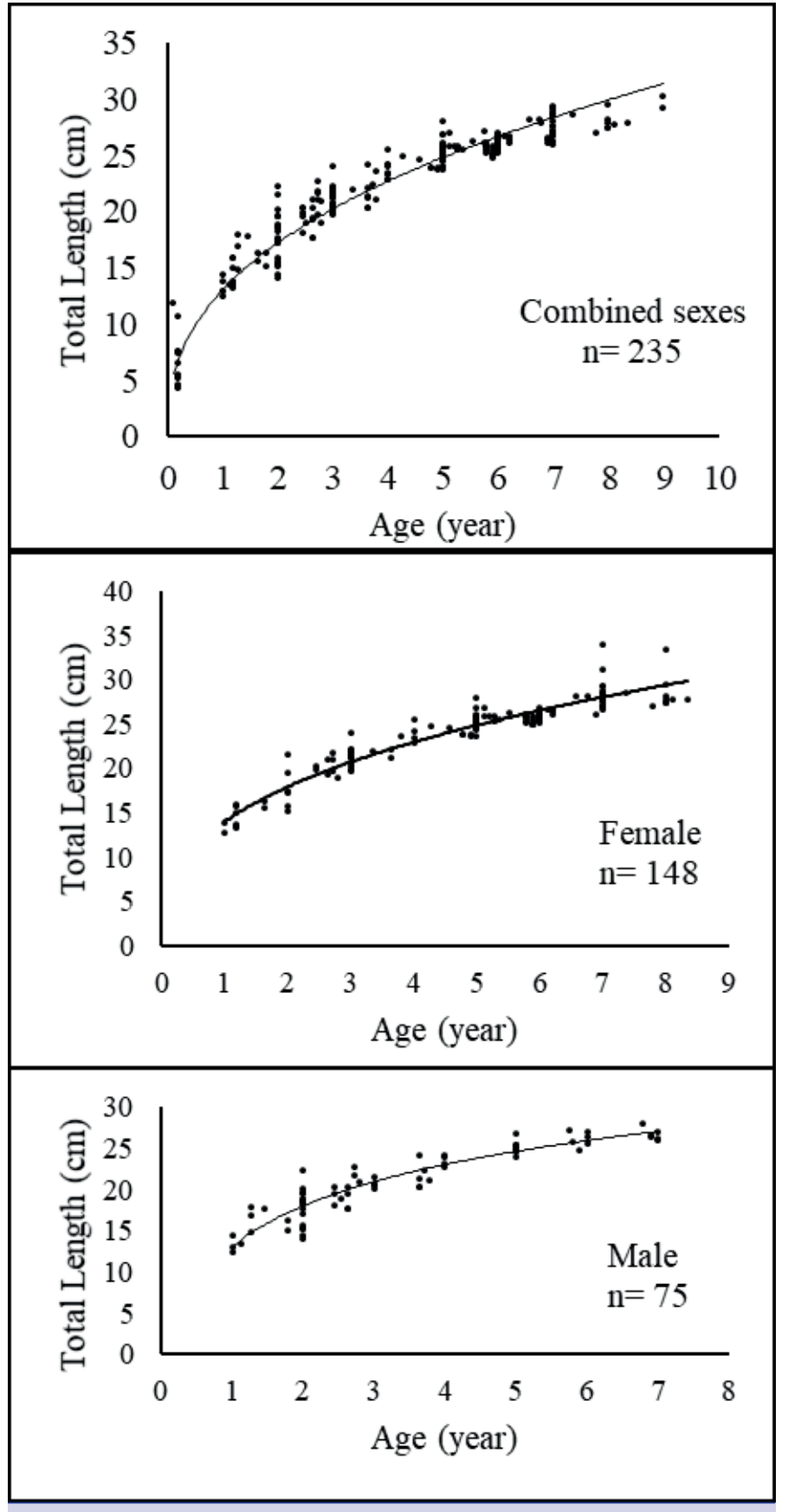

Figure 4. Age-Length relationship of common sole.

variations. On the other hand, these variations could have originated due to some environmental factors such as pollution (Authman et al, 2015), fishing and temperature (Tu et al., 2018) and especially food availability (Ujjania et al., 2012; Gupta \& Banerjee, 2015). Furthermore, size variation may be affected by genet- 
Table 2. Age-length key for the common sole in Güllük Bay based on otolith readings

\begin{tabular}{|c|c|c|c|c|c|c|c|c|c|c|c|}
\hline & \multicolumn{10}{|c|}{ Age (years) } & \multirow{2}{*}{$\mathbf{N}$} \\
\hline & 0 & 1 & 2 & 3 & 4 & 5 & 6 & 7 & 8 & 9 & \\
\hline $2-4.9$ & 3 & & & & & & & & & & 3 \\
\hline $5-7.9$ & 7 & & & & & & & & & & 9 \\
\hline 8-10.9 & & 1 & & & & & & & & & 1 \\
\hline $11-13.9$ & & 5 & 5 & & & & & & & & 10 \\
\hline $14-16.9$ & & 3 & 16 & & & & & & & & 19 \\
\hline $17-19.9$ & & & 13 & 12 & & & & & & & 25 \\
\hline $20-22.9$ & & & 3 & 25 & 10 & & & & & & 38 \\
\hline $23-25.9$ & & & & 1 & 8 & 35 & 25 & 7 & & & 76 \\
\hline $26-28.9$ & & & & & & 3 & 14 & 25 & 6 & & 48 \\
\hline 29-31.9 & & & & & & & & 3 & 3 & 2 & 8 \\
\hline Total & 10 & 9 & 37 & 38 & 18 & 38 & 39 & 35 & 9 & 2 & \\
\hline Mean $(\mathrm{cm})$ & 5.7 & 12.8 & 16.8 & 20.5 & 22.6 & 24.9 & 25.8 & 26.8 & 28.0 & 30.3 & 235 \\
\hline S.D. & 1.2 & 1.2 & 2.3 & 1.4 & 1.4 & 0.7 & 0.5 & 0.6 & 0.5 & 1.5 & \\
\hline
\end{tabular}

Table 3. Age-length key for female common sole in Güllük Bay based on otolith readings

\begin{tabular}{|c|c|c|c|c|c|c|c|c|c|c|}
\hline & \multicolumn{9}{|c|}{ Age (years) } & \multirow{2}{*}{$\mathbf{N}$} \\
\hline & 0 & 1 & 2 & 3 & 4 & 5 & 6 & 7 & 8 & \\
\hline \multicolumn{11}{|l|}{$2-4.9$} \\
\hline \multicolumn{11}{|l|}{$5-7.9$} \\
\hline \multicolumn{11}{|l|}{$8-10.9$} \\
\hline $11-13.9$ & & 2 & 2 & & & & & & & 4 \\
\hline $14-16.9$ & & 1 & 9 & & & & & & & 10 \\
\hline $17-19.9$ & & & 4 & 6 & & & & & & 10 \\
\hline $20-22.9$ & & & 2 & 19 & 4 & & & & & 25 \\
\hline $23-25.9$ & & & & 1 & 7 & 25 & 16 & 4 & & 53 \\
\hline $26-28.9$ & & & & & & 2 & 13 & 20 & 6 & 41 \\
\hline $29-31.9$ & & & & & & & & 2 & 3 & 5 \\
\hline Total & & 3 & 17 & 26 & 11 & 27 & 29 & 26 & 9 & \\
\hline Mean $(\mathrm{cm})$ & & 13.7 & 16.5 & 21.1 & 23.4 & 24.8 & 25.8 & 28.2 & 28.5 & 148 \\
\hline S.D. & & 2.0 & 2.2 & 1.1 & 1.3 & 0.9 & 0.5 & 1.7 & 1.9 & \\
\hline
\end{tabular}

\begin{tabular}{|c|c|c|c|c|c|c|c|c|c|}
\hline & \multicolumn{8}{|c|}{ Age (years) } & \multirow{2}{*}{$\mathbf{N}$} \\
\hline & 0 & 1 & 2 & 3 & 4 & 5 & 6 & 7 & \\
\hline \multicolumn{10}{|l|}{$2-4.9$} \\
\hline \multicolumn{10}{|l|}{$5-7.9$} \\
\hline 8-10.9 & & 1 & & & & & & & 1 \\
\hline $11-13.9$ & & 3 & 3 & & & & & & 6 \\
\hline $14-16.9$ & & 2 & 7 & & & & & & 9 \\
\hline $17-19.9$ & & & 9 & 6 & & & & & 15 \\
\hline $20-22.9$ & & & 1 & 6 & 6 & & & & 13 \\
\hline $23-25.9$ & & & & & 1 & 10 & 9 & 3 & 23 \\
\hline $26-28.9$ & & & & & & 1 & 1 & 5 & 7 \\
\hline $29-31.9$ & & & & & & & & 1 & 1 \\
\hline Total & & 6 & 20 & 12 & 7 & 11 & 10 & 9 & \\
\hline Mean $(\mathrm{cm})$ & & 12.4 & 17.0 & 20.1 & 22.3 & 25.1 & 26.1 & 26.6 & 75 \\
\hline S.D. & & 1.4 & 2.1 & 1.5 & 1.5 & 0.7 & 0.8 & 0.6 & \\
\hline
\end{tabular}


Table 5. Age-length distribution of common sole from Güllük Bay and other locations

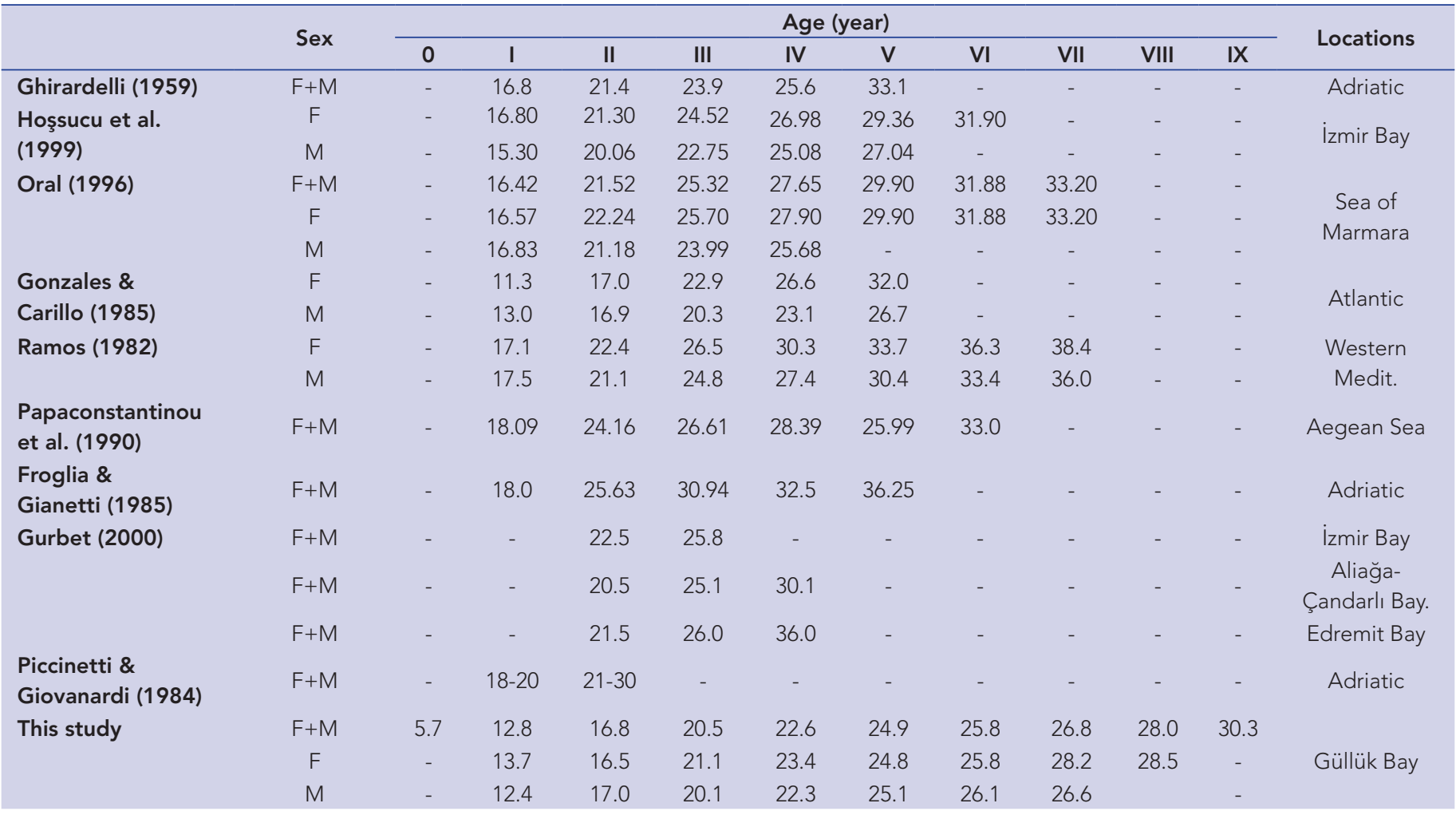

Table 6. Some growth parameters of common sole from Güllük Bay and other study locations

\begin{tabular}{|c|c|c|c|c|c|c|c|}
\hline & Sex & $\mathbf{n}$ & $K\left(y r^{-1}\right)$ & $t_{0}(y r)$ & $\mathrm{L}_{\infty}(\mathrm{cm})$ & $\varnothing^{*}$ & Locations \\
\hline Ramos (1982) & M & 151 & 0.240 & -1.085 & 38.80 & 2.56 & Western Mediterranean \\
\hline \multirow[t]{3}{*}{ Vianet et al. (1989) } & $\mathrm{F}$ & 287 & 0.270 & -0.410 & 51.56 & 2.86 & \\
\hline & M & 274 & 1.030 & -0.070 & 26.38 & 5.86 & \multirow[t]{2}{*}{ Gulf of Lion } \\
\hline & $\mathrm{F}+\mathrm{M}$ & 561 & 0.240 & -0.770 & 48.83 & 2.76 & \\
\hline \multirow[t]{2}{*}{ Deniel (1990) } & $\mathrm{F}$ & 558 & 0.329 & 0.075 & 48.20 & 2.88 & \multirow{2}{*}{ France } \\
\hline & M & 351 & 0.397 & 0.093 & 42.40 & 2.85 & \\
\hline \multirow[t]{3}{*}{ Oral (1996) } & $\mathrm{F}+\mathrm{M}$ & 523 & 0.273 & -1.166 & 37.12 & 2.58 & \\
\hline & $\mathrm{F}$ & 218 & 0.729 & -1.065 & 35.79 & 2.97 & \multirow[t]{2}{*}{ Sea of Marmara } \\
\hline & M & 206 & 0.629 & -0.911 & 28.63 & 2.71 & \\
\hline Stergiou et al. (1997) & & & 0.380 & -0.410 & 34.90 & 2.67 & Aegean Sea \\
\hline \multirow[t]{2}{*}{ Türkmen (2003) } & $\mathrm{F}$ & 553 & 0.181 & -1.550 & 29.95 & 2.21 & \multirow{2}{*}{ İskenderun Bay } \\
\hline & M & 550 & 0.221 & -1.310 & 26.03 & 2.18 & \\
\hline Mehanna \& Salem (2012) & & 2179 & 0.330 & -0.450 & 44.36 & 2.81 & Egypt \\
\hline \multirow[t]{3}{*}{ Mehanna et al. (2015) } & $\mathrm{F}+\mathrm{M}$ & & 0.580 & -0.003 & 35.81 & 2.87 & \\
\hline & $\mathrm{F}$ & & 0.620 & -0.009 & 36.24 & 2.91 & \multirow[t]{2}{*}{ Egypt } \\
\hline & M & & 0.550 & -0.060 & 34.77 & 2.82 & \\
\hline \multirow[t]{3}{*}{ This Study } & $\mathrm{F}+\mathrm{M}$ & 1136 & 0.208 & -0.032 & 33.95 & 2.38 & \multirow{3}{*}{ Güllük Bay } \\
\hline & $\mathrm{F}$ & 607 & 0.236 & -0.037 & 31.98 & 2.38 & \\
\hline & M & 529 & 0.324 & -0.030 & 29.11 & 2.44 & \\
\hline
\end{tabular}


ic factors (Exadactylos et al, 2013). Phi-prime values of previous studies showed no differences with the present study ( $p>0.05)$. Therefore, the growth of common sole could not be correlated with just food availability and other environmental factors could be responsible for length at age variation.

$\mathrm{L}_{\infty}$ values are different from other studies (Table 6). This variation could emanate from different sampling gears and maximum catch lengths. Moreover, the $\mathrm{L}_{\infty}$ of combined sexes was higher than the $L_{\infty}$ of males and females. This situation was due to the incorporation of unsexed individuals into the age estimation.

\section{Possible effects on growth}

Growth of fishes is different from other animals. After maturation, although growth slows down due to the transferring of resources to reproductive parts of body, it continues (Enberg et al., 2008). Flatfishes also have similar lifecycles to other fishes and this similarity is likely to reflect temperature, food availability and energetics (Nash \& Geffen, 2015).

Growth of common sole were revealed by different observations and considerations. According to some researchers, growth of common sole does not depend on food limitation (van der Veer et al., 2001; Pihl, 1989). Exadactylos et al. (2013) mentioned a potential genetic effect on growth and size variability in cultured common sole and turbot. Nash \& Geffen (2015) stated that many flatfish species show an increased growth rate within increasing exploitation levels due to a decrease in population size and an increase in food availability under these circumstances. On the other hand, during the first 2 to 3 years, juveniles are found in nurseries before migrating to deeper waters (ICES, 2012) and also food availability and temperature effects the growth on the nursery grounds (Nash \& Geffen, 2015).

Growth may be affected by interspecific food competitions. Vinagre (2007) found that priority of cohort colonization of both S. senegalensis and S. solea in estuaries effects growth rate and S. senegalensis has a higher growth rate than S. solea. In early colonization, low competition and high food availability may affect the growth rate. Besides, Molinero et al. (1991) determined that diets of $S$. solea and $S$. senegalensis are very similar in the western Mediterranean and $S$. senegalensis is now extending its range to the west Mediterranean Sea and is thought to be competing with $S$. solea, at least in the north-west part of the basin (Tous et al., 2015). Similarly, S. solea may have food competition with other flatfishes (e.g. Microchirus ocellatus, Monochirus hispidus, Citharus liguatula, Arnoglossus spp. etc.).

Except competitions, water pollution may be another reason that effects fish growth. Bhatnagar \& Devi (2013) stated that good water quality is important for survival and growth of fish. Güllük Bay sampling area is the most important aquaculture center in Turkey. Yıldız et al. (2002) conducted a study in Güllük Bay about marine pollution sources and they mentioned the Sarıçay river (sewage from the Milas district discharges into the Sarıçay river), Güllük Harbor and marine traffic, tourism, aquaculture systems, domestic wastes and atmospheric pollutants may have a pressure on Güllük Bay. Fish growth may be negatively affected by the existence of the aforementioned pollution types.

\section{CONCLUSION}

Monitoring of biological parameters constitutes the main data for fisheries. Therefore, fishery management should be structured on biological data to understand the status and to manage fish stocks. More studies should be conducted in different fishing areas to gain more information about wild stocks for managing commercial flatfish fisheries and aquaculture trials.

Conflicts of interest: The authors have no conflicts of interest to declare.

Ethics committee approval: This study was conducted in accordance with ethics committee procedures of animal experiments.

Financial Disclosure: This study was funded by Muğla Sıtkı Koçman University, Scientific research Project Office with Phd thesis project number BAP 13/119.

Acknowledgement: We would like to thank Boğaziçi and Göltürkbükü sole fishermen for their valuable support and to Burak YABA and Cihan BULUT for checking grammar and spelling.

\section{REFERENCES}

Authman, M. M. N., Zaki, M. S., Khallaf, E. A. \& Abbas, H. H. (2015). Use of Fish as Bio-indicator of the Effects of Heavy Metals Pollution. Journal of Aquaculture Research and Development, 6, 328. [CrossRef]

Beverton, R. J. H. \& Holt, S. J. (1956). A review of methods for estimating mortality rates in fish populations, with special reference to sources of bias in catch sampling. Rapports et Procés-verbaux des Réunions, 140, 67-83.

Bhatnagar, A. \& Devi, P. (2013). Water quality guidelines for the management of pond fish culture. International Journal of Environmental Sciences, 3(6), 1980-2009.

Cerim, H. \& Ateş, C. (2016). Selectivity of trammel nets (80 and $90 \mathrm{~mm}$ mesh size) for common sole (Solea solea linnaeus, 1758) used in Güllük Bay. Ege Journal of Fisheries and Aquatic Sciences, 33(4), 361-366. [CrossRef]

Cerim, H. (2017). Güllük Körfezi'nde Uzatma Ağları ile Avcııı̆ı Yapılan Dil Balığı (Solea Solea lınnaeus, 1758)'nın Bazı Biyolojik ve Popülasyon Parametrelerinin Belirlenmesi. Muğla Sıtkı Koçman Üniversitesi, Fen Bilimleri Enstitüsü, Su Ürünleri Mühendisliği Anabilim Dalı, Doktora Tezi.

Deniel, C. (1990). Comparative study of growth of flatfishes on the west coast of Brittany. Journal of Fish Biology, 37, 149-166. [CrossRef]

Enberg, K., Dunlop, E. S. \& Jorgensen, C. (2008). Fish growth. In S. E. Jorgensen \& B. Fath, (Eds.), Encyclopedia of Ecology (pp. 1564-1572). Amsterdam: Elsevier. ISBN 9780444637680 [CrossRef]

Eschmeyer, W. N. \& Fong, J. D. (2017). Species of Fishes by family/subfamily, http://researcharchive.calacademy.org/research/ ichthyology/catalog/ SpeciesByFamily.asp (Access Date: 10 March 2018)

Exadactylos, A., Malandrakis, E. E, Panagiotaki, P. \& Geffen A. J. (2013). The development of size variation in Dover sole, Solea solea and turbot, Scophthalmus maximus: genetic variability between different geographical and among year class farmed strains. Aquaculture Research, 44, 1912-1925. [CrossRef]

Froglia, C. \& Giannetti, G. (1985). Growth of common sole Solea vulgaris Quensel in the Adriatic Sea (Osteichthyes, Soleaidae). Rapports et procés-verbaux des réunions Commission internationale pour l'exploration scientifique de la Mer Méditerranée, 29(8), 91-93. 
Ghirardelli, E. (1959). Contribution à l'étude de la biologie des soles (Solea solea) en moyenne Adriatique. Reports General Fisheries Council for the Mediterranean, 5, 481-487.

González, J. A. \& Carrillo, J. (1985). Estudio de la edad y crecimiento del lenguado, Solea vulgaris vulgaris Quensel 1806, del Noroeste de Africa. Simposio Internacional Sobre Las Areas De Afloramiento Mas Importantes Del Oeste Africano, Instituto De Investigaciones Pesqueras, Barcelona, 2, 921-934.

Gupta, S. \& Banerjee, S. (2015). Length-weight relationship of Mystus tengara (Ham.-Buch., 1822), a freshwater catfish of Indian subcontinent. International Journal of Aquatic Biology, 3(2), 114-118.

Gurbet, R. (2000). Variation in the stock assessment and distribution of demersal fish biomass in the Northern Aegean Sea. Ege Journal of Fisheries and Aquatic Sciences, 17(3-4), 105-117.

Hossucu, B., Kaya, M. \& Taşkavak, E. (1999). An investigation of growth parameters and otolith-total length relationship of Solea solea (I., 1758) (Pisces: Soleidae) in İzmir Bay. Israel Journal of Zoology, 45, 277-287.

ICES, (2012). Report of the Working Group on the Assessment of Demersal Stocks in the North Sea and Skagerrak (WGNSSK). ICES CM 2012/ACON:13. Copenhagen, ICES.

Khan, S. \& Khan M. A. (2014). Importance of Age and Growth Studies in Fisheries Management. Reviewed Proceedings of National Seminar on NGSV. Next Generation Sciences: Vision 2020 and Beyond. Rohtak, Haryana, India, 194-201.

Legendre, A. M. (1805). Nouvelles Méthodes pour la Détermination desOrbites des Comètes, Firmin Didot, Paris.

Mehanna, S. F. \& Salem, M. (2012). Fisheries Regulations Based on Yield Per Recruit Analysis for the Common Sole Solea Solea (Soleidae) at Bardawil Lagoon, Mediterranean Coast of Sinai, Egypt. Egyptian journal of animal production, 49(1), 113-121.

Mehanna, S. F., Abo El-Regal, M. \& Aid, N. M. (2015). Critical Lengths, Mortality Rates and Relative Yield per Recruit of the Common Sole Solea solea from the Egyptian Mediterranean Coast off Alexandria. Egyptian Journal of Aquatic Biology and Fisheries, 19(2), 13-20. [CrossRef]

Molinero, A., García, E. \& Flos., R. (1991). Comparative study of the feeding habits for two species of sole: Solea vulgaris and Solea senegalensis. Special Publications of the European Society of Aquaculture, 14, 219-220. [CrossRef]

Nash, R. D. M. \& Geffen, A. J. (2015). Age and growth. In R. N Gibson, R. D. M. Nash, A. J. Geffen \& H. W. van der Veer (Eds.), Flatfishes: Biology and Exploitation (pp. 207-241). Chichester, UK: John Wiley \& Sons, Ltd. ISBN: 978-1-405-14338-7. [CrossRef]

Oral, M. (1996). Biological aspects of Common Sole (Solea vulgaris Quensel, 1806) in the Sea of Marmara. Phd. Thesis. İstanbul University, ìstanbul, pp. 70.

Papaconstantinou, C., Petrakis G. \& Caragitsou, E. (1990). Natural history of sole (Solea vulgaris L. 1758) in the Amvrakikos Gulf (Greece). Rapports et Procès-Verbaux des Réunions Commission Internationale pour l'Exploration Scientifique de la Mer Méditerranée, 32, 266.

Pauly, D. \& Munro, J. L. (1984). Once more on the comparison of growth fish and invertebrates. ICLARM Fishbyte 2, 1-21.
Pauly, D. (1993). Fishbyte section editorial. Naga, the ICLARM Quarterly, 16(2-3), 26.

Piccinetti, C. \& Giovanardi, O. (1984). Données biologiques sur Solea vulgaris Quensel en Adriatique. FAO Fisheries and Aquaculture Report, 290, 117-121.

Pihl, L. (1989). Abundance, biomass and production of juvenile flatfsh in southeastern Kattegat. Netherlands Journal of Sea Research, 24, 69-81. [CrossRef]

Ramos, J. (1982). Estuido de la edad y crescimiento del lenguado Solea solea (L. 1758) (Pisces, Soleidae). Invesfigacion Pesquera, 46(1), 15-18.

Ricker, W. E. (1973). Linear regressions in fishery research. Journal of the Fisheries Research Board of Canada, 30, 409-434. [CrossRef]

Stergiou, K. I., Christou, E. D., Georgopoulous, D., Zenetos, A. \& Souvermezoglou, C. (1997). The Hellenic seas: physics, chemistry, biology and fisheries, Oceanography and Marine Biology, 35, 415-538.

Teixeira, T. F. A. (2007). Genetic diversity and population structure of Solea solea and Solea senegalensis and its relationships with life history patterns. Msc Thesis, Universidade de Lisboa Faculdade de Ciências Departamento de Biologia Animal, 61p.

Tous, P., Sidibe, A., M bye, E., de Morais, L., Camara, Y. H., Adeofe, T. A., Monroe, T., Camara, K., Cissoko, K., Djiman, R., Sagna, A. \& Sylla, M. (2015). Solea solea. The IUCN Red List of Threatened Species 2015: e.T198739A15595369. [CrossRef]

Tu, C. Y., Chen, K. T., \& Hsieh, C. H. (2018). Fishing and temperature effects on the size structure of exploited fish stocks. Scientific reports, 8(1), 7132. [CrossRef]

TUiK, (2016). Fishery statistics. Turkish statistical Institute, http://www. turkstat.gov.tr/PreTablo.do?alt_id=1005 (Access Date: 10 March 2018)

Türkmen, M. (2003). Investigation of Some Population Parameters of Common Sole, Solea solea (L., 1758) from İskenderun Bay. Turkish Journal of Veterinary and Animal Science, 27, 317-323.

Ujjania, N. C., Kohli, M. P. S. \& Sharma, L. L. (2012). Length-weight relationship and condition factors of Indian major carps (Catla catla, Labeo rohita and Cirrhinus mrigala) in Mahi Bajaj Sagar, India. Research Journal of Biology, 2(1), 30-36.

Ulutürk, E., Kaya, M. \& Irmak, E. (2012). The importance of flatfishes (Pisces/Pleurronectiformes) of the world and Turkish seas. Ege Journal of Fisheries and Aquatic Sciences, 29(2), 101-108. [CrossRef]

Van der Veer, H. W., Dapper, R. \& Witte, J. I. J. (2001). The nursery function of the intertidal areas in the western Wadden Sea for 0-group sole Solea solea (L.). Journal of Sea Research, 45, 271-279. [CrossRef]

Vianet, R., Quignard, J. P. \& Tomasini, J. A. (1989). Age et croissance De Quatre Poissons Pleuronectiformes (Flet, turbot, barbue, sole) Du Golfe Du Lion. Cybium, 13(3), 247-258.

Vinagre, C. (2007). Ecology of the juveniles of the soles, Solea solea (Linnaeus, 1758) and Solea senegalensis Kaup, 1858, in the Tagus estuary. PhD thesis. Universidade De Lisboa Faculdade De Ciências Departamento De Biologia Animal, pp. 214.

Yıldız, H., Doğan, H. M. \& Urla. Ö. (2002). Muğla ili Güllük Körfezi'nde Deniz Suyu Kirliliğinin Coğrafi Bilgi Sistemleri ve Uzaktan Algılama Sistemleri ile İzlenmesi. Tarla Bitkileri Merkez Araştırma Enstitüsü Dergisi, 11(1-2), 142-149. 